\title{
"YOU'VE LIVED IN X TOO LONG, WHEN...": A VIEW OF THE WORLD THROUGH COMIC LISTS (EXPATRIATES' HUMOUR ON RU.NET)
}

\author{
Maria Yelenevskaya
}

\begin{abstract}
This article discusses social antecedents, patterns of reproduction and innovation, and the communicative function of the comic lists which use the pattern "You've lived in X too long, when..." Originally borrowed from the English-language web sites, the idea of describing peculiarities of life in different countries has become popular on Ru.net among Russian-speaking expatriates and residents of Russia. The comic list format serves as a convenient template for individual or collaborative portrayal of those features of various countries that seem strange or weird to outsiders. While teasing the ways and habits of the other, writers of the lists reflect about their own culture, revealing ambivalent attitudes and a conflict of allegiances. Collaborative creation of the lists and heated discussions of their content point to the interactive nature of Internet folklore. Moreover, the users' comments indicate that the lists do not only serve for entertainment, but are valued as a source of information about the world outside the country of origin.
\end{abstract}

Key words: computer-mediated communication, humour of expatriates, identity, Ru.net, self-reflection

\section{INTRODUCTION}

Without fearing to sound old-fashioned or "out of paradigm" Arvo Krikmann, a tireless investigator of folk culture, appeals to folklorists to archive and number jokes: joke indices are essential tools for researchers because our knowledge of how individual jokes and joke patterns are born and evolve, how they travel and what factors contribute to their dissemination is still fragmentary (Krikmann 2009). The nature of fieldwork undertaken by collectors of jokelore has undergone considerable changes in the last decade since much of the humour exchange today occurs in computer-mediated communication (CMC) and requires archiving of material posted on humour portals and in live journals, in chat groups and discussion forums. Humour can be also found on the sites of companies and agencies using it as a gimmick (Alekseevskii 2009b: 152), and humourous messages in text, video and audio formats are circulated in viral 
e-mail messages. Like in the pre-Internet era, Internet humour appears in cycles, and the goal of this essay is to present distinctive features of the cycle of Ru.net humour "You have lived in $\mathbf{X}$ too long, when..." tracing its social antecedents, patterns of reproduction and innovation, and the communicative function.

\section{COMIC LISTS AS A SUB-GENRE OF VERBAL HUMOUR}

Comic lists came to be investigated by folklorists on the basis of English-language material in the 1970s as a subgenre of office folklore that became popular thanks to the spread of fax machines and photocopiers (Dundes 1983; Dundes \& Pagter 1987). This subgenre is represented by lists of definitions and instructions, rules and recommendations, specific features of various groups, objects and phenomena, and so on. Its precursors can be found in the literary tradition, one of the better known examples being the Devil's Dictionary by Ambrose Bierce (1967). Alan Dundes and Carl R. Pagter indicate that some of the popular lists currently circulating in the USA have items that were popular back in the 1930s and 1940s (Dundes \& Pagter 1987: 26). Comic lists are topical and cover a vast diversity of subjects. Like jokes, they mirror folk attitudes to such "eternal" issues as gender relations, social hierarchies and cultural conventions (see, e.g., Dundes \& Pagter 1987: 17, 29-31). Some of the lists reflect social conflicts and inter-group struggle for power. In fact, the popularity of office folklore was primarily analysed by American folklorists as an expression of the employees' protest against a depersonalised corporate environment (see, e.g., Preston 1994, and Roemer 1994). Finally, comic lists are compiled in response to political events, as exemplified by "War in Iraq Humour", which includes such lists as "Top 10 Things That Will Get You Kicked out of Iraq", “Top 10 Things Iraq's Information Minister Has to Say about the War", “Top 10 Saddam Hussein's Tips for a Romantic Evening", etc. http://politicalhumor.about.com/ od/iraq/Iraq_Jokes_and_Iraq_War_Humor.htm, 10/02/2010. ${ }^{1}$ The Internet has given comic lists a new lease on life. In her classification of the Internet humour, Limor Shifman found them to be among the four most popular "old" types of humour, whose dissemination has accelerated since it is no longer dependent on the use of office-based equipment (Shifman 2007: 196).

Research into Soviet and post-Soviet humour seldom, if ever, refers to comic lists. And no wonder. Unlike the officially sponsored and "ideologically correct" lore, popular jokelore in the Soviet period was subversive for the system, and was disseminated orally. When photocopiers and fax machines appeared in Soviet offices they were carefully guarded and inaccessible to rank-and-file 
employees for fear the new equipment would be used for disseminating unwanted information. This does not mean that the subgenre of comic lists did not exist at all as these would be compiled and read aloud in skit shows, at birthday parties, student performances and in $K V N^{2}$ contests. Being too long for oral dissemination, many of the lists were familiar only to narrow circles of the intelligentsia and remained in private archives. This subgenre remained on the periphery of Russian jokelore until the advent of the Internet, which gave a boost to the popularity of longer humourous texts, such as amusing personal experience stories (baiki), parodies of poetry and jocular quizzes (Lutovinova 2009; Yelenevskaya 2008). Today a random search on Yandex yields thousands of pages that offer comic lists starting with the following words

- 10 signs of/that ...

- 10 commandments of ...

- 10 characteristic features of...

Since the opening words are neutral, comic lists in the search results alternate with serious ones, including professional advice, business recommendations and religious discussions (for example, "10 signs of a true Christian".) Most comic lists are tagged as prikoly (conversational Russian for 'jokes and pranks') and deal with diverse issues, not differing from those that are covered in internationally popular jokes. Ethnic humour is presented on such lists as "10 characteristic features of an average" American, Russian, Israeli, etc., which reprocess familiar stereotypes. The lists discussed in this article also deal with ethnic, or rather national stereotypes as viewed through the eyes of expatriates.

\section{HUMOUR OF THE RUSSIAN DIASPORA}

The first post-Soviet decade was marked by mass emigration from the countries of the former Soviet Union (FSU). Wherever sizeable numbers of Russian speakers settled they established their own newspapers and magazines. Whether in Australia or Finland, Germany or Greece, Israel or the U.S.A., these editions included humour columns, which reprocessed old Soviet jokes, reprinted humour from the Russian media and translated into Russian popular jokes of the host country. In addition, editors encouraged readers to send their own contributions dealing with amusing experiences in the new countries. With the growing popularity of Ru.net the bulk of émigré humour migrated to the net (Gorny 2009; Yelenevskaya 2009).

Since humour is among the most important mechanisms that help people overcome psychological and social stress confronting us in everyday life (Lefcourt \& Martin 1986: 1) it is particularly important in the life of migrants. Hardly any 
émigrés from the FSU, even those who moved to a new country on a repatriate ticket, were immune to a culture shock. The lack of language proficiency (most Russian speakers among ex-Soviets were monolinguals), confrontation with unfamiliar customs, the loss of social network, and, finally, hostile attitudes to newcomers on the part of some members of the receiving society - these stress factors called for the mobilisation of intra-group solidarity. Humour also proved to be a useful tool in the interpretation of common past and establishment of the group's position vis-á-vis the host society. It simplified cultural adjustment and secondary socialisation (see Protassova 2006; Yelenevskaya 2009; Zilberg 1995).

\section{BETWEEN GLOBALISATION AND GLOCALISATION}

Like many other products of post-Soviet media and mass culture, "You've lived in $\mathbf{X}$ too long, when..." lists were borrowed from the U.S.A. In the pre-Internet period they appeared in American newspapers and magazines presenting ironic and amusing reflections of expatriates on various cultures as viewed by travelling Americans ${ }^{3}$.

Since in the Soviet times foreign travel was restricted, life outside the USSR and images of ethnicities inhabiting other countries appeared mainly in international jokes, displaying ethno-stereotypes shared by many cultures. These were familiar to Soviet people primarily from literature, movies and the media. The choice of characters featuring in these jokes was also limited, primarily confronting traditional Russian values, habits and behavioural patterns with those presumed to be stereotypically American, English, French and German. ${ }^{4}$ Notably, in the Soviet jokes in which representatives of different nations find themselves in unusual situations or compete against each other, Russians do not necessarily emerge as endowed with moral virtues or winners. Rather, their self-image is critical, exposing laziness, indifference to success, excessive drinking, disrespect for law, and unruliness (Shmeleva \& Shmelev 2002: 75-82). In most cases the setting of these jokes was some vague no-man's land or the Soviet territory, where foreigners had to grapple with much-derided peculiarities of Soviet life. Humour about "ours" in alien lands was scarce, and either related to the Jewish emigration, or to the blunders made by those who were trusted by the authorities to travel to the West. Opening of the borders and mass emigration of the 1990s made the theme of "ours abroad" much more visible in the Russian jokelore of the post-Soviet period.

The lists "You've lived in $\mathbf{X}$ too long, when..." provide a convenient template for individuals and groups to create a portrait of a foreign land, its people and customs describing the unfamiliar nature and climate and those features of society that seem strikingly odd, irrational, weird or bizarre to a newcomer. 
My search on Yandex yielded lists about 40 countries on all the continents. ${ }^{5}$ Of these 32 are devoted to the countries of the so called "far abroad" and 8 to the "near abroad" (countries of the FSU). Since the latter group does not deal with the émigré culture, but is driven by the changes in the life of the newly formed states, these lists were not included in the analysed sample. Material for the study of the lists on the "far abroad" was drawn from 150 sites which included humour hubs, such as anekdot.ru, discussion forums, blogs and pages of commercial companies, primarily travel agencies. Content analysis was applied in order to outline dominant themes and motifs, and text analysis was used in order to check stability of the texts and/or their innovation patterns.

On the one hand, the diversity of countries ironically discussed in the format of comic lists gives a glimpse of the vastness of the geography of the Russianspeaking world today; on the other hand, it would be misleading to link the existence or absence of some country on these lists to the activity of Russianspeaking communities. ${ }^{6}$ Thus, there are three lists on Malaysia, which appear on Ru.net primarily on the sites providing information for tourists, but not a single one on New Zealand, although its Russian-speaking residents are active in Internet forums, ${ }^{7}$ and so on. Two lists in my sample, on Australia and Denmark, appear only once, others, like those on Germany, Italy, Norway, Spain, and the USA keep travelling from site to site as single posts or in combination with lists on other countries, with readers' comments or without. The shortest list in the sample is on Sweden: it consists of just six items, and the longest one is on the UK numbering 204 items. Some sites demonstrate collaborative creation of the lists. A case in point is the rubric "Your Opinion" of the humour hub Anekdot. $r u$ in which various participants contributed observations about America and other countries under assumed Internet names (nicknames or simply nicks) (see, discussion about the creation of the lists at http://gb.anekdot.ru/scripts/gb .php? component $=$ gb\&id $=1 \&$ fu $=0 \&$ sort $=0 \&$ date $=2000-03-17,15 / 05 / 2009)$. The peak of circulation of the lists about various countries on $R$ u.net fell during the years 2003-2006, but new posts keep popping up. The latest lists in my sample were uploaded in March 2010.

The authorship of most lists is not acknowledged, nor is the original source mentioned. In fact, because of the instability of many sites, it may not be easy or possible to trace some of them. Some users introduce or conclude their posts with the following: "just found this in the vast space of the net", "borrowed from others", "[I'm] posting a bayan" (bayan is a kind of accordion which in Russian Internet slang is used pejoratively to denote a stale joke ${ }^{9}$ ). Other posters give links to the sites where they found the list they copy, or give the nickname of the blogger who posted it earlier. Mentioning of real names of the authors is exceptional. Thus some items of the American list were contributed by Dmitrii 
Verner, an astrophysicist and the creator of Anekdot.ru. (http://www.vmizm. net/if.html, 15/03/2010), but on most sites posting the American list neither his name, nor the nicknames of other contributors are mentioned. The most frequently posted Israeli list also appears anonymously although it was written by the St. Petersburg writer and playwright, Igor Gindin shortly after immigration (Gindin 2003). ${ }^{10}$ The Serbian list was created by Irina Antanasievich (http:// iraan.livejournal.com/24279.html, posted on 15/07/05, accessed on 16/03/2010) ${ }^{11}$, and Daria Kirienko wrote a list on Malaysia entitling it "Fairytales about Malaysia" and posted it in her blog on 20/04/2007 at http://upita.livejournal. com/27037.html. Two years later she updated it (http://community.livejournal. com/inostranki/793780.html, accessed on 10/03/2010), and this later version was copied to other sites. There is a good chance that like other popular lists it will finally "lose signature" and will continue its Internet journey anonymously. These metamorphoses of Internet humour: authored $\rightarrow$ anonymous $\rightarrow$ appropriated by another author, as well as the shuttling of the humourous texts between the net, the mass media and oral lore occur in different genres as demonstrated in Mikhail Alekseevskii 2009a and 2010.

Some lists overlap. Thus, the Canadian list recycles what was earlier written about America, and the lists on Latvia/Riga and Lithuania are almost identical (see, e.g., http://www.meeting.lv/guides/event.php?id=7B59ss154, posted on 05/11/2001, http://forum.umora.biz/index.php?act=Print\&client=pri nter\&f=35\&t=2006, posted in June-July 2007, http://www.imho.ws/showthread. php?t=50222, posted on 05/02/2004, all three sites accessed on 29/03/2010.) Similar overlaps are characteristic of lists in English, with the Finnish, Norwegian and Swedish lists to a large extent mirroring each other. These overlaps testify once again that cultures in contact may seem similar to more distant others, who tend to generalise and miss the subtleties familiar to the insiders or members of the cultures in contact.

"Copy-paste" versions of the lists alternate with edited or updated texts in which the posters either choose only those items that they consider particularly apt for describing the host country, or change the wording, or add new items. A case in point is the Israeli list which appears on some sites in modified versions with added items mocking economic and social problems confronting émigrés at a later stage of the integration process and reflecting better familiarity of the writers with socio-political and interethnic problems of the host country (http:// opredelitel.narod.ru/israel.htm, http://danisimus.livejournal.com/109412.html, posted on 13/08/2009, both sites accessed on 17/03/2010). The German, Irish, Spanish, Dutch and some other lists also exist in several versions. Random comparisons with lists, posted on various countries in Google, in English show that some of the items on Russian lists may have been merely translated; some 
others borrowed the idea adapting it to the country described. A case in point is twin items about names. On the forum of American expatriates in Moscow we find an item implying how expatriates' social networks change and at the same time teasing about what is seen as addiction to prototypical local names: "You've lived in Russia for too long when... you know more than 60 Olgas" (http://expat.ru/forum/showthread.php?t=9000, posted on 31/05/2004, accessed on 05/03/2010). In the numerous identical posts of the Russian list about Norway the same idea is expressed in an even more exaggerated fashion: "when... you know 50 Mortons, 40 Tronds and 30 Chelgas", see e.g., http://www.averkiev.com/ forum/showthread.php?t=3974, posted by Gulya E' on 21/01/2005, accessed on 01/06/2009). One of the lists on Malaysia gives the borrowed item an additional touch pointing to the multi-ethnic nature of the host society "when ...among your acquaintances there are five Chans (men and women), ten Mohammeds (men) and five Indian girls named Jaeah" (http://community.livejournal.com/ inostranki/793780.html, posted on 08/04/2009, accessed on 10/03/2010). These repetitions and borrowings notwithstanding, most observations on the Russian lists still differ from those made by expatriates from other countries. Even when creators of the list dedicated to a particular country observe the same phenomena often reproducing pervasive internationally known stereotypes, the writers use the norms and customs of their own society and culture as the basis for comparison. ${ }^{12}$ These norms form an implicit antithesis with the items included in comic lists "You've lived in $\mathbf{X}$ too long, when..."

\section{OBSERVING OTHERS, REFLECTING ABOUT THE SELF}

Infatuation with travelling is one of the hallmarks of our time. When tourists come to a new country they search for the unusual and exotic and often end up seeing the attractive façade without getting but a glimpse of the real life of the country they are visiting. By contrast, migrants get into the very midst of reality, so to say, its backyard, where one has to cope with the mundane, be it everyday food habits, sanitary norms, or relations with neighbours. At the same time, the longer and closer the contacts the better one gets to know social conventions, shared values and cultural tastes of the host society, whether they are openly stated and demonstrated or remain obscure to outsiders. To analyse dominant themes and motifs, items that appeared on the lists devoted to at least three different countries were divided into 14 categories: nature and climate, language use, eating and drinking habits, recreational activities, dress code and styles, etiquette and forms of politeness, conventions of social time, interpersonal relations and communication styles, inter-ethnic relations, culture 
maintenance, respect for law and rules, political culture, national pride, and attitudes to the environment. Some of the items can be classified as belonging to more than one category. Thus, items about food consumption can contain observations about eating habits and also maintenance of culture. At the same time, they often give a glimpse of the difference in the conventions of social time at home and in host countries. Items about language use are combined with observations about norms of politeness, communication styles and maintenance of culture. Ironic descriptions of dress codes point to differences in tastes and the etiquette; in addition they are linked to the management of life in different climates, and so on. Due to volume-wise limitation, I'll now focus on three of the listed categories to demonstrate how they are developed and what they reveal about contemporary Russian perception of other cultures.

\section{Eat to live or live to eat?}

Items devoted to food and drink appear on every list, as if to testify again that this feature of material culture is not only among the most accessible ones for observation, but is also meaningful for comparing different life styles. Globalisation has done little to change Russian culinary tastes. The popularity of imported western products, when they entered the Russian market did not last long. In every country with a sizeable Russian-speaking community, food stores selling traditional Russian food and delicacies are among the foremost successful businesses. The comic lists clearly show émigrés' loyalty to familiar tastes:

- Your eating habits no longer cause surprise or trigger exclamations Y-a-a-ack! What's that? (UK)

- You've stopped complaining and finally discovered all the necessary ingredients for pilaf, borsch and herring-in-a-fur coat [a vegetable salad with herring]. (Malaysia)

- You know where to buy leaven, semolina and poppy seeds... and also sprats, buckwheat and good vodka. (France)

Although none of the foods mentioned above speak of luxury, ironic descriptions of favourite local foods are presented as dominated either by those products that are either too tasteless or too spicy, or associated with the menu of the poor in Russia:

- You distinguish 20 sorts of sauerkraut by taste and you can use it in 20 different dishes. (Austria) 
- You know what the "day of the new herring is" and you also know that herring is the only Dutch delicacy worthy of attention. (the Netherlands)

- You stopped referring to "pasta" as "macaroni" [used in everyday Russian as generic for various types of pasta] and you know over ten different types of pasta. (Italy)

The farther apart is the Fatherland and the host country geographically and culturally, the more items about strange and suspiciously looking, tasting and smelling foods we find on the comic lists. Tasting what is considered inedible is akin to breaking a taboo and is viewed as a small act of defiance:

- You eat raw mushrooms in salads and it no longer amazes you. (UK)

- You can eat shewarma without fearing to find a little dog's tail in it. (United Arab Emirates)

- You believe that an egg that was kept in warm temperature for a fortnight is much tastier than a fresh one. (China)

Two other motifs that appear on the analysed lists are worthy of attention because they touch upon two trends characteristic of food consumption of our contemporaries. One is obsession with low-calorie foods that are in vogue in affluent Western countries:

- You do your shopping in fat-free-food stores but you can spend 30 minutes driving all around a parking lot in search of the slot that is one minute closer to the store. (USA)

Émigrés of the 1990s still remember food shortages at home and perceive preoccupation with "healthy foods" as whimsical, in particular when it is not combined with other attributes of a healthy life style, most often viewed as walking long distances on foot. Driving anywhere, including to a fitness room around the corner, is derided in many lists.

Another trend is globalisation of food habits:

- A good Friday is the Friday when you have a good portion of Indian curry, the spicier the better, and drink a couple of pints of beer with it. (UK)

Austrians who consider Hungarian gulash and Italian pizza their national dishes, Germans and Spaniards who do not even try to eat with chopsticks in Chinese restaurants, and the Chinese who have perfected the art of eating bread 
with chopsticks - all these ironic remarks bring up the topic of globalisation which is still perceived as a novelty by émigrés from Russia, although today in big Russian cities one can find restaurants offering ethnic foods from various corners of the world.

In his seminal book, on ethnic humour around the world, Christie Davies remarks that differences in eating habits are an easy target for deriding the other because they mark visible and fundamental differences in everyday behaviour. They serve to express superiority over the group at whose expense people laugh, preserve boundaries between groups and classes, and warn against breaking taboos (Davies 1990: 276-306). All these motifs are found on the studied lists and suggest that humourous observations about eating habits of the other in most cases have social undertones.

\section{All in good time?}

Temporality plays an important part in making sense of a new environment. Since time is a social construct, when immersed in it people experience the influence of a multitude of times permeating their daily life (Adam 1995: 12) in the ways different from what is familiar to them. Depending on the geographic position and the climate, the day is divided differently in various parts of the world, and different hours are allocated to work and leisure. Thus, in the hot Mediterranean climate work starts early, but there is a break in the afternoon and a lull in activities in the hottest afternoon hours, which makes it difficult for newcomers to adjust to opening hours of various institutions:

- You finally managed to learn opening hours of shops, banks, post offices, state institutions and restaurants. (Italy)

In addition, there are no strictly fixed times for meals in Russia, and respect for keeping their schedule in other countries is perceived as an oddity:

- People who call to discuss business issues from 14 to 16 make you furious, as they disturb your digestion. A war may be waged, but lunch is to be eaten as scheduled. (Spain)

Migrants who settle down in the countries that do not live according to the Julian calendar have an additional difficulty of getting used to a different temporality mediating individual lives and most societal interaction (Mills 2000: 104). This motif emerges on the lists compiled by new Israelis and residents of Muslim countries where religious institutions and religious rituals have a major impact on everyday life of all the residents, even if they are secular and belong to other confessions: 
- You've learned that a week starts on Sunday, a day in the evening, and a year in September, but each time on a different date. (Israel)

- Once a year for a month you have to hide when you eat or smoke. (Dubai)

The last item may puzzle those who are unfamiliar with Ramadan, the sacred period for the Muslims. This is the ninth month of the Islamic calendar, when observant people refrain from eating, drinking, smoking and having sex from dawn until sunset. ${ }^{13}$ Like many other items linked to traditions and customs of the host country, this one implies that even when newcomers do not identify with traditions of their hosts, they try not to alienate them, and if they choose to violate them, they do so surreptitiously. In many respects, traditions in Christian countries are closer to those in Russia. Even in the Soviet period of militant atheism many of the Soviet holidays borrowed rites and rituals from the Russian Orthodox tradition. Yet even in Christian countries it is not easy for migrants to get used to local holidays, be they religious or secular. Holidays are landmarks in the calendar and their observance is linked to shared memory. They form an essential element of individual and group identity and for this reason different dates and different rituals associated with them are mentioned on many lists:

- Among your favourite holidays is the Queen's birthday (although you don't know of which one), Labour Day, races in Melbourne and the inglorious death of a quarter of male population of Australia at the walls of some Turkish fortress. (Australia)

- You start preparing for Christmas in October... which, naturally will be BEFORE the New Year. (Germany)

- Your children know what St. Martin's Day is, but your wife is unfamiliar with the 8th of March. (Germany)

- Celebrating the New Year in the middle of summer is as natural for you as having dinner after 10 or whistling in public places. (Argentina)

Authors of several lists ironically observe that holidays, that were much loved and joyfully celebrated back home, are ousted from their lives by new ones that are not properly understood and do not stir up festive feelings. The lists show once again that the New Year still remains the most loved holiday for ex-Soviets (Fialkova \& Yelenevskaya 2007: 276-277), but in the absence of snow, and without the traditional fir-tree and the exchange of gifts, it loses much of its 
charm. Some of the lists also reflect upon the commercialisation of Christmas, and the wave of consumerism preceding it.

Another motif linked to conventions of social time has to do with different communication styles and basic etiquette. It is well known that friendship is one of the key concepts of Russian culture (Shmelev 2005; Wierzbicka 2002). For many Russian speakers, friends are no less important than family. It is considered to be a virtue to give up whatever you are doing in order to help a friend in need, and spontaneity, such as dropping by at a friend's place unannounced is perceived as a token of closeness rather than impoliteness. Confronted with the people who plan their social life and guard specific hours and days for the self and family, Russians experience ambivalent feelings: on the one hand, these conventions seem too regimented; on the other hand their advantages are too obvious not to be admitted:

- You try to fix the date when you come to visit your friends at least a month beforehand, and darn it, you find it convenient. (Denmark)

- You believe calling your friends after 9 p.m. or on Sunday is comparable with working in your garden on Sunday and deserves severe criticism. (Switzerland)

The two examples above illustrate the difference in the handling of time by what can be called in Edward T. Hall's terms monochronic and polychronic cultures. The former is characteristic of low-involvement people, who compartmentalise time, and the latter appeals to those, who are more involved and tend to be engaged in several operations simultaneously (Hall 1981: 153-155). Lynn Visson, who studied mixed Russian-American marriages, noted that Russians are very flexible in their handling of things planned, and that being late seems to be part of the Russian makeup (Visson 2001: 142-145). Many of the analysed lists deal with punctuality, and show that this may be changing in post-Soviet Russia. In the attitude, if not in performance, respect for punctuality prevails. There are only two teasing remarks about precision in time turned into a cult:

- You apologise for being 30 seconds late. (Switzerland)

- You are angry if the bus arrives at 12:39 instead of 12:37. (Norway) On the contrary, a careless attitude to schedules and failure to keep promises to do things or deliver services on time are numerous:

- $\quad$ One cannot be late for an appointment with you, because you will come later than your partner anyway. (Argentina) 
- When told that something will be done on Wednesday, note that you should call on Friday to ask when it is ready. (Ireland)

- When you hear that some business will be finished tomorrow morning, you don't bother checking for at least a week or a month. (Cyprus)

- Leaving for an appointment you say, "I'll be there in five minutes." Arriving one and a half hours later you say, "F*cking traffic!!!" (United Arab Emirates)

The lists examined reveal once again that the practical problems of time management constitute many a dilemma when representatives of different cultures interact in everyday life. Thomas Luckmann observes that the inner time of those who live and act together must be reciprocally adjusted (1991: 156). When participants of these interactions have internalised different conventions of time management such adjustment is problematic and the emerging conflict of betrayed expectations gives grounds for mutual derision.

\section{It takes all sorts to make a world}

Whether they settle in the countries whose policies are guided by ethnic nationalism or in countries proclaiming political ideals of multiculturalism, migrants often experience suspicion and hostility on the part of the host society. Ex-Soviets are no exception, which makes them alert to the attitudes of the receiving societies to members of their own group and other minorities.

- You believe that a Romanian is an occupation. (Spain)

In many countries migrants occupy specific niches in the job market. Although some of them are highly-skilled workers, they do not feature on the lists and rather one gets the impression that the fate of migrants is to be engaged in hard manual labour or to work in service industries. Indeed, the majority of migrants are low-paid, and many of them penetrate affluent Western countries illegally. These people are mercilessly exploited and neglected socially. In common parlance, their ethnonyms come to signify their occupations. A case in point is Spain, where Romanian males are primarily employed in construction; another example is Israel, where a "Filipina" came to denote a female or male nurse taking care of the elderly.

Some lists point to migrants' ghettoisation in cities that appear to be divided into "white" and "coloured" areas. They ironically admit that the desirable neighbourhoods, testifying to socio-economic success of the residents, remain an elusive dream for newcomers, including ex-Soviets: 
- In the back of your mind you note that if there is no white person left in the subway car, you are more than five stops away from the town centre. (Sweden)

- You and your neighbours, Kong, Mansour, Janis, Salem, Noori and Jiao, consider your neighbourhood to be primarily white and European, while all migrants live in some other area of Sydney. (Australia)

Some items imply that immigrant groups are distinguished by various types of deviant behaviour, be it filling residential areas with stinking garbage, endangering others by careless driving, or having an addiction to drinking and drugs. Moreover, they are blamed for any deterioration in the life of the host society:

- You easily distinguish between the odour of Surinamese and Indonesian marijuana. (the Netherlands)

- You believe every drunkard to be Polish. (Italy)

- You put the blame for all your misfortunes on illegal immigrants from Albania ... Having read this text you are convinced it is sabotage on the part of illegal immigrants from Albania. (Greece)

Interethnic conflicts, economic hardships and increased migration in the territory of the FSU have had a significant impact on the mentality of post-Soviet individuals breeding intolerance of ethic others. Some lists reveal scornful attitudes to ideals of multiculturalism and political correctness in interethnic relations viewing them as hypocritical or absurd:

- You are crazy about all Negroes but you hate every single one in particular. You are not a racist, you don't like racists but you are convinced that Negroes cannot rule the country. (South Africa)

- You refuse to watch "War and Peace" because there is not a single Negro in it, and you are against racism. (USA)

- You feel great sympathy for Chechen black-asses and discuss this with everyone but you hate all Arabs and will never spend a cent on them because they are gradually settling all over France. (France)

Note that none of the lists use the words "Afro-Americans" or "blacks" but only "negroes", although the writers in the lists are unlikely to be unaware of its stigmatising connotations. We also come across scornful folklore-related phraseology and pejorative nicknames like "indo-paki" for Indians and Paki- 
stanis and "black asses" which in contemporary Russian labels a wide variety of ethnic groups, ranging from residents of the Caucasus to Central Asians and Palestinians (see Fialkova \& Yelenevskaya 2007: 94-97, 106).

Although rarely, some list writers explicitly reflect about intolerance of one's own group, mocking alienation not only from various others, but even from the co-ethnics:

- You are not surprised that when all of a sudden your wife switches over to Spanish in supermarkados it means that your former compatriots are nearby.

- You curse Czechs for being dumb and Russians for showing off; you hate Germans, Slovaks, Ukrainians... in fact, in terms of hatred and misanthropy you are becoming a true cosmopolitan. (Czech Republic)

\section{AMBIVALENCES OF DIASPORIC LIVES}

Russian lists "You've lived in $\mathbf{X}$ too long, when..." pose the question about their lasting popularity. What makes Internet users create new items on the known lists and add their own? Why are there heated discussions about them in forums and why are they unanimously placed in the rubrics "humour" and "pranks"? Some of the lists are too sketchy; others are excessively long and contain items that are either lexico-semantic doubles or contradict each other. Their compilers seldom use a play on words or exploit the satirical potential of bilingualism and biculturalism that would seem natural for humour juxtaposing cultures. While some contributions are sharp in their perception of host cultures and reflections about the self, others add details that give but a superficial picture of the country portrayed, lacking originality and relying primarily on over-exploited stereotyping. One possible answer lies in that, like other forms of Internet folklore, they a means of self realisation (Kõiva \& Vesik 2009: 100) and help contributors sort out their experiences. Secondly, they foster solidarity among co-ethnics, irrespective of where they live. While piling up details, some of them disparaging their host countries, others teasing members of their own group, compilers of these lists rely on their readers' recognition of those peculiarities of life in their new countries that are different from what they were used to at home. This expectation of shared values and agreement in the perception of the other turns into what Giselinde Kuipers called a "tiny conspiracy" of the joke teller and his audience (Kuipers 2006: 180). This is confirmed by frequent praises that follow lists in forums and blogs: 
- Thanks for a good laugh! This topic is really cool! (http://www.russianparis.com/forum/index.php?topic=3165.0, accessed on 17/04/2010)

- Good girl! You did a great job writing it all up! These things, they also bring me side-splitting laughs or make me angry... (http://blogs. mail.ru/mail/o_dokukova/40EEE0104D05F536.html, accessed on $17 / 04 / 2010)$

- Great! Sounds a bit like Italy too (-) (http://nat--ka.livejournal. com/148057.html, accessed on 17/04/2010)

Readers, living in the country portrayed, offer additions to the lists or contest certain items. Residents of other countries note similarities with their own observations, these being a special source of amusement and seen particularly often in the comments to the lists on Mediterranean countries. Moreover, some "green-horns" and posters unfamiliar with the country described in a particular list ask for explanations, when certain things puzzle them or remain unclear.

The second explanation for the amusement created by these lists is the ambiguity of the insider/outsider position implied by their authors. One of the main dilemmas for immigrants anywhere is preserving or discarding one's identity. And it is precisely this conflict of allegiances within a group as a whole and within individuals that is reflected in the lists. How much do their compilers identify with their host countries and their people? Do they convey the message that adaptation is inevitable, or is it a warning against assimilation? Naturally, this varies from list to list and depends on the degree of the writers' integration, as well as on his/her personal style and tolerance. In some cases, the ambiguity is resolved in the last item of the list which functions like a punch line in jokes:

- You no longer want to go home. (Norway)

- Damn it, despite all of this, you do like this country! (Austria)

- By no means will you go back home! (Czech Republic)

- You curse everyone and everything in France; nevertheless, you don't want to move away anywhere, even to your own historical Motherland. (France)

In the absence of such statements, it is the correlation of statements in which irony is directed at the hosts or at the self that, as well the use of lexemes with positive or negative evaluative sememes, and the use of possessive pronouns "our" or "their" when referring to the host country, that give clues to the writ- 
ers' acceptance of or alienation from the host country. On some lists, however, these indicators are absent and the ambiguity remains unresolved.

Notably, only on two lists in the sample (one version devoted to the USA, and one to the UK) do we find items ridiculing stupidity of the host population as implied by poor knowledge of geography and the habit of following manuals and instructions blindly. It is well known, from the literature on ethnic humour, that the most frequent theme in deriding others is presenting them as stupid, inept and ignorant (see, e.g., Davies 1990: 10-39; Salomon 2007; Zhdanova \& Frukhtmann 2008). The absence of this theme in most lists also suggests blurring of boundaries between the newcomers and the hosts in the perception of the former.

Readers' comments show that they have no trouble resolving identity ambiguities. The positive evaluation of the countries portrayed prevails and is often emphatically expressed: "I also want this...", "Jeez! I also want to live there!!!", "I couldn't tear myself off it....Your life there is so good!"

Heated discussions around the lists show that, besides viewing them as entertainment, many Internet users regard them as a source of information useful for tourists, potential migrants and for those who are just starting their life in a new place:

- We already have a link on the site "You've lived in America too long if", and it is COOL! How much headache, how many embarrassing situations could have been avoided had I read all this simple wisdom BEFORE my first visit to the United Northamerican States! (http:// gb.anekdot.ru/scripts/gb.php?component=gb\&id=1\&page=18\&sort= $0 \&$ date $=2000 \& f u=0$, posted on $17 / 03 / 2000$, accessed on $28 / 06 / 2009$ )

These and similar comments in praise of comic lists confirm that the boundarymarkers between humour and seriousness are not absolute (Billig 2005: 184). The reliance of contemporary globe trotters on what is referred to as "useful advice from all over the world" again proves the persuasive power of humour and its high demand in communication and socialisation.

\section{NOTES}

1 When referring to Internet sources I indicate the dates when I accessed them.

${ }^{2} K V N$ - is the acronym of the Club of the Witty and Resourceful - a popular TV programme that was among the first live shows on Soviet TV.

3 Although I failed to find any references to these lists in scholarly literature, my American informants remembered seeing a variety of these lists, with newspaper readers sending their contributions to the editors. 
4 The vagueness of a Soviet person's image of the world is also reflected in other genres of urban folklore. For example, in his investigation of Russian urban ballads about distant lands, Nekludov shows that while their geographic settings are extremely diverse plots and the characters involved are limited and stereotypical (Nekludov 2008).

5 Some of the lists do not deal with the whole country, but only with one of its provinces or states, e.g., Bavaria in Germany or Texas in the USA. There are also lists on cities, such as New York and Prague, but the items on the "local" lists to a large extent overlap with those on the lists of their corresponding countries. Parallel to this there is a collection on various Russian areas and cities, e.g., "Piter" (diminutive for St. Petersburg), Chukotka, Sakhalin, and so on. There is a popular list on a very special semi-public, semi-private space with a culture of its own - student dorms that made it to the comic lists of this sort. Finally, the same pattern is used on the lists which concentrate on various periods of time trying to capture its characteristic features, e.g., You've lived in the 90-s, or in the 21st century too long, when...

6 This is true about the comic lists dedicated to the FSU, e.g., the only list on Central Asia describes peculiarities of life in Tajikistan, but there is nothing on Kazakhstan, Uzbekistan, or Kyrgyzstan, three other Central Asian countries with large Russianspeaking minority groups.

7 Internet activities of Russian-speaking New Zealanders can be viewed at http://top100. narodnz.co.nz/russian_new_zealand/, 29/03/2010. They include regular news issues, information about immigration and jobs, some business information and the discussion forum "Novyi Zelandets", Russian for a "New Zealander."

8 Unfortunately, I failed to find the dates of these posts, although the thread reconstructing the joint creation of this list appears at http://www.vmizm.net/if.html, 27/03/2010.

9 See the explanation of the possible origins of this slang word at http://lurkmore. $\mathrm{ru} / \% \mathrm{D} 0 \% 91 \% \mathrm{D} 0 \% \mathrm{~B} 0 \% \mathrm{D} 1 \% 8 \mathrm{~F} \% \mathrm{D} 0 \% \mathrm{BD}, 15 / 01 / 2011$. Despite its wide use on the net and in oral communication, the spelling of the word remains unstable: баян, боян, байан.

${ }^{10}$ I. Gindin does not seem to be particularly happy about the swift "folklorisation" of his text (http://igor-gindin.livejournal.com/profile), but he is not the only victim of this pervasive Internet phenomenon, which is not plagiarism, per se, rather careless "copy-paste" anonymity.

${ }^{11}$ First posted in the author's live journal, this list was published in the rubric "Serbia in Russian" of the first periodical in Serbian in Russia in April 2009. See its Internet version at www.balkany.net, 16/03/2009.

12 The only list in the sample which was merely translated from English is on Russia. Although it derides powerlessness of the rank-and file Russian citizen, attachment to drinking and idiosyncrasies of Russian urban life, it remains popular despite the fact that some of its items have become dated (http://netnotes.narod.ru/sbm/text/t34. html, 22/03/2010).

${ }^{13}$ Compare this to the Jewish joke mocking those who violate the rules of Sabbath and the Day of the Atonement: A Christian, employed as a servant by a Jewish family, remarks that on the whole, Jews are nice people despite some funny habits. Once a week they smoke in the toilet, and once a year they even eat there. 


\section{REFERENCES}

Adam, Barbara 1995. Timewatch: The Social Analysis of Time. Cambridge: Polity Press. Alekseevskii, Mikhail 2009a. "Chto mne vodka v letnii znoi...": problemy tekstologii fol'klora v Internete. [What's the Trouble in Drinking Vodka on a Sultry Summer Day...": Textological problems of Investigating Internet Folklore.] Internet and Folklore. Moscow: GRTsF, pp. 71-89.

Alekseevskii, Mikhail 2009b. Internet v fol'klore ili fol'klor v Internete (Sovremennaia fol'kloristika i virtual'naia real'nost') [Internet in Folklore or Folklore on the Internet (Contemporary Folkloristics and Virtual Reality, in Russian).] pp. 151-166, http://mdalekseevsky.narod.ru/alekseevsky-congress.pdf, last accessed on 3 March 2012.

Alekseevskii, Mikhail 2010. Anekdoty ot Zuganova: Fol'klor v politicheskoi bor'be. [Jokes courtesy of Ziuganov: Folklore in Political Struggle.] Antropologicheskii Forum, Vol. 12, pp. 71-89.

Bierce, Ambrose 1967. The Enlarged Devil's Dictionary. Edited by E. J. Hopkins. London: Penguin Books.

Billig, Michael 2005. Laughter and Ridicule: Towards a Social Critique of Humour. London: Sage.

Davies, Christie 1990. Ethnic Humor around the World: A Comparative Analysis. Bloomington \& Indianapolis: Indiana University Press.

Dundes, Alan 1983. Office Folklore. In: Richard M. Dorson (ed.) Handbook of American Folklore. Bloomington: Indiana University Press, pp. 115-120.

Dundes, Alan \& Pagter, Carl R. 1987. When You're up to Your Ass in Alligators: More Urban Folklore from a Paperwork Empire. Detroit: Wayne State University Press.

Fialkova, Larisa \& Yelenevskaya, Maria 2007. Ex-Soviets in Israel: From Personal Narratives to a Collective Portrait. Detroit: Wayne State University Press.

Gindin, Igor 2003. You've Lived in Israel Too Long When... Narod Moi, No. 4 (297), http://www.jew.spb.ru/ami/A297/A297-092.html, last accessed on 3 March 2012.

Gorny, Eugene 2009. More than Humor: Jokes from Russia as a Mirror of Russian Life. In: Gerard Goggin \& Mark McLelland (eds.) Internationalizing Internet Studies: Beyond Anglophone Paradigms. New York \& London: Routledge, pp. 9-95.

Hall, Edward Twitchell 1981. The Silent Language. New York: Anchor Press.

Kõiva, Mare \& Vesik, Liisa 2009. Contemporary Folklore, Internet and Communities at the Beginning of the 21st Century. In: Mare Kõiva (ed.) Media and Folklore. Contemporary Folklore IV. Tartu: ELM Scholarly Press, pp. 97-120.

Krikmann, Arvo 2009. Jokes in Soviet Estonia. Folklore: Electronic Journal of Folklore, Vol. 43, pp. 43-66.

Kuipers, Giselinde 2006. Good Humor, Bad Taste: A Sociology of the Joke. Humor Research 7. The Hague: Mouton de Gruyter.

Lefcourt, Herbert M. \& Martin, Rod A. 1986. Humor and Life Stress: Antidote to Adversity. New York \& Berlin \& Heidelberg \& Tokyo: Springer-Verlag.

Luckmann, Thomas 1991. The Constitution of Human Life in Time. In: J. Bender \& D. Wellbery (eds.) Chronotypes: The Construction of Time. Stanford: Stanford University Press, pp. 151-166. 
Lutovinova, Olga 2009. Baika v virtual'nom fol'klore. [Amusing Personal Experience Stories in Virtual Folklore.] Russkii Yazyk za Rubezhom, Vol. 2, pp. 77-78.

Mills, Melinda 2000. Providing Space for Time: The Impact of Temporality on Life Course Research. Time and Society, Vol. 9, No. 1, pp. 91-127.

Nekludov, Sergei 2008. Russkii gorozhanin poet o dalekikh stranakh: "filoekzoticheskii" sloi gorodskoi ballady. [The Russian City-dweller Sings about Distant Lands: Philo-exotic Layer of the Urban Ballad.] Fol'klor i Post-Fol'klor:struktura, tipologia, semiotika, http://www.ruthenia.ru/folklore/neckludov41.htm, last accessed on 3 March 2012.

Preston, Michael J. 1994. Traditional Humor from the Fax Machine: "All of a Kind". Western Folklore, Vol. 53, No. 2, pp. 147-169.

Protassova, Ekaterina 2006. Iumor v russkoiazychnoi presse Finlandii. [Humour in the Russian-Language Press in Finland.] Diasporas, Vol. 4, pp. 53-70.

Roemer, Danielle M. 1994. Photocopy Lore and the Naturalization of the Corporate Body. The Journal of American Folklore, Vol. 107, No. 423, pp. 121-138.

Salomon, Hagar 2007. The Ambivalence over the Levantinization of Israel: "David Levi" jokes. Humor, Vol. 20, No. 4, pp. 415-442.

Shifman, Limor 2007. Humor in the Age of Digital Reproduction: Continuity and Change in Internet-Based Comic Texts. International Journal of Communication, Vol. 1 , pp. 187-209.

Shmelev, Alexey 2005. Druzhba v russkoi iazykovoi kartine mira (Friendship in the Russia Linguistic Picture of the World, in Russian). In: Anna Zalizniak et al. (eds.) Kluchevye idei russkoi iazykovoi kartine mira. Moscow: Languages of the Slavic Culture, pp. 289-306.

Shmeleva, Elena \& Shmelev, Alexey 2002. Russkii anekdot: Tekst i rechevoi zhanr. [Russian anecdote: A Text Type and a Speech Genre.] Moscow: Languages of Slavic Culture.

Visson, Lynn 2001. Wedded Strangers: The Challenges of Russian-American Marriages. New York: Hippocrene Books.

Wierzbicka, Anna 2002. Russian Cultural Scripts: The Theory of Cultural Scripts and Its Applications. Ethos, Vol. 30, No. 4, pp. 401-432.

Yelenevskaya, Maria 2008. Humor in the Russian-Language Media in Israel: Cultural Antecedents, Genres and Themes. Israel Studies in Language and Society, Vol. 1, No. 2, pp. 36-58.

Yelenevskaya, Maria 2009. "Ours abroad” As a Theme of Humor on Ru.net: Changing Values, Competing Loyalties. Russian Journal of Communication. Special Issue, The Russian Anekdot As Cultural Genre, Discourse and Performance, Vol. 2, No. 3/4, pp. 267-287.

Zhdanova, Vladislava \& Frukhtmann, Yakob. 2008. Natsional'nost' - durak: "poluchuzhie" v imperskikh anekdotakh. [Ethnicity: A Fool: "Semi-aliens in Imperial Jokes.] In: A. S. Arkhipova \& M. A. Gister (eds.) Kirpichiki: Folkloristics and Cultural Anthropology Today. Moscow: Russian State University of Humanities, pp. 481-497.

Zilberg, Narspy 1995. In-group Humor of Immigrants from the Former Soviet Union to Israel. Israel Social Science Research, Vol. 1, No. 10, pp. 1-22. 